and maybe we are guilty of something

we have no idea what he has given

his life for, though I think

it has something to do with

a monster under the bed.

$\mathrm{He}$ is growing old before our eyes, and no one can catch him now,

no one, that is, except his lost mother.

\title{
Vito Takes His Neighbor's Dog for a Drive
}

A woodpecker is duplicating hellbent stitches

and, in the ravine, a ballet dancer is slithering toward a bunch of onions.

Vito stands by the heaving cedars and watches a salad parachute into a trapeze net.

He remembers a sexual encounter in a janitor's closet in an airport, zone of shelves darting into a beige milestone, a cactus repulsing its own penumbra,

spun sugar slouching around without a vocation.

She said: "I don't know how I feel about being an angel

without a muddy carcass clattering around

in fluffiness without shoestrings or flippers."

Later, she said: "I might like being a nail driven into a cameo, or calling Charlotte Brontë collect in the middle of the night."

Vito returned, after an absence of seven years.

His neighbor's dog was restless and wanted to join the rodeo.

Something happened in the night - two pterodactyls

were circling - a man was flying to Pakistan

to meet his mother after eight years - chewing gum -

the statistics, bellowing, the statistics, a fire- 
a newborn calf, full of pride and fierce hunger, leapt and that's when Vito had had enough. He dressed, very deliberately, with the firm knowledge that his sole duty at this hour - to tap out an existence within these flames - was to drive drive and drive that neighbor's dog around the world.

\section{AM A FinN}

I am standing in the post office, about to mail a package back to Minnesota, to my family. I am a Finn. My name is Kasteheimi (Dewdrop).

Mikael Agricola (1510-1557) created the Finnish language. He knew Luther and translated the New Testament. When I stop by the Classé Café for a cheeseburger

no one suspects that I am a Finn.

I gaze at the dimestore reproductions of Lautrec on the greasy walls, at the punk lovers afraid

to show their quivery emotions, secure in the knowledge that my grandparents really did emigrate from Finland in 1910-why

is everybody leaving Finland, hundreds of thousands to Michigan and Minnesota, and now Australia? Eighty-six percent of Finnish men have blue

or grey eyes. Today is Charlie Chaplin's one hundredth birthday, though he is not Finnish or alive: "Thy blossom, in the bud

laid low." The commonest fur-bearing animals are the red squirrel, musk-rat, pine-marten and fox. There are about 35,000 elk. 